\title{
Aretaeus of Cappadocia and His Treatises on Diseases
}

\section{Kapadokyalı Aretaeus ve Hastalıklar Üzerine Yazdığı Eseri}

\author{
Halil TEKINER \\ Erciyes University, The Gevher Nesibe Institute of the History of Medicine, Kayseri, Turkey
}

Corresponding Author: Halil TEKINER / E-mail: htekiner@erciyes.edu.tr

\begin{abstract}
Aretaeus of Cappadocia is considered as one of the greatest medical scholars of Greco-Roman antiquity after Hippocrates. He presumably was a native or at least a citizen of Cappadocia, a Roman province in Asia Minor (Turkey), and most likely lived around the middle of the second century (AD) His eight volume treatise, written in lonic Greek, entitled On the Causes, Symptoms and Cure of Acute and Chronic Diseases remained unknown until the middle of the $16^{\text {th }}$ century when, in 1552, the first Latin edition was published. In this work, Aretaeus offered clinical descriptions of a number of diseases among which he gave classic accounts of asthma, epilepsy, pneumonia, tetanus, uterus cancer and different kinds of insanity. He differentiated nervous diseases and mental disorders and described hysteria, headaches, mania and melancholia. He also rendered the earliest clear accounts on coeliac disease, diphtheria and heart murmur, and gave diabetes its name.
\end{abstract}

KEYWORDS: Biography, Diagnosis, Disease, History of medicine

Öz

Kapadokyalı Aretaeus, Antik dönemde yaşamış tıp yazarları arasında adı Hipokrat'tan sonra anılan en önemli isimlerden birisidir. Milattan sonra ikinci yüzyılda Roma İmparatorluğu'na bağlı Kapadokya eyaletinde doğduğu düşünülen Aretaeus, Akut ve Kronik Hastalıkların Nedenleri, Belirtileri ve Tedavileri başlıklı sekiz ciltlik bir eser kaleme almıştır. Eski İyonca yazılmış bu eser 16. yüzyılın ortalarına kadar unutulmuş, 1552 yılında ise Latince çevirisi yayınlanmıştır. Aretaeus, bu eserinde astım, epilepsi, tetanos, uterus kanseri, zatürre ve bazı akıl hastalıklarının da aralarında bulunduğu birçok hastalığın klinik bulgularını tanımlamış; sinir sistemi hastalıkları ile akıl hastalıklarını birbirinden ayırmış; baş ağrısı, histeri, mani ve melankoliyi tarif etmiştir. Çölyak hastalığı, difteri ve üfürümün de klinik bulgularını ilk kez tanımlamış ve diyabet hastalığına bu adı vermiştir.

ANAHTAR SÖZCÜKLER: Biyografi, Tanı, Hastalık, Tıp tarihi

\section{INTRODUCTION}

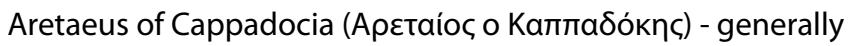
styled Aretaeus, the Cappadocian - is considered one of the greatest medical scholars of Greco-Roman antiquity after Hippocrates. His extant work, entitled On the Causes, Symptoms and Cure of Diseases is of immense significance in the history of medicine. In this eight-book treatise, Aretaeus offered clinical descriptions of many diseases with great accuracy.

\section{ARETAEUS of CAPPADOCIA}

Our knowledge of Aretaeus' biography is very limited and is mostly derived from circumstantial comments in his own writings as well as those in other medical texts from the succeeding centuries. As his epithet indicates, Aretaeus presumably was a native or at least a citizen of Cappadocia, a Roman province in Asia Minor, near the modern city of Kayseri, Turkey $(2,21)$. He was born between the time of Cornelius Celsus (30 BC-30 AD) and Galen of Pergamon (131-c. $200 \mathrm{AD}$ ) (4). It is also generally believed that Aretaeus studied in Alexandria and spent some time in Egypt, then practiced medicine in Rome, although there is no real evidence for these assumptions $(2,22)$.
In terms of his medical approach, in principle Aretaeus adhered to the Pneumatic School which held that health depended on bodily eukrasia, a harmonious balance between the basic elements (hot, cold, wet, and dry), and pneuma (refined airy element or spirit), a vital power which bound the elements $(17,28)$. Although the Doctrine of Pneuma goes back to Hippocrates, it did not become the basis of a school until Athenaeus of Sicily founded one in the first century AD.

Hippocrates, Thucydides and Homer are among the earlier authors who influenced Aretaeus (4). In fact, Aretaeus demonstrated his admiration of Hippocrates (fourth century BC) not only by writing in the dialect of lonic Greek, which bears a considerable resemblance to the language of Hippocrates, but also in sometimes illustrating his theories with Hippocratic aphorisms and quotations taken from the Corpus Hippocraticum (22). Although he does not mention the name of the Greek historian Thucydides (fifth century BC), Aretaeus refers to the suspicion of the poisoning of the wells in Piraeus, which the historian mentions in his description of the $430 \mathrm{BC}$ plague of Athens (4). Aretaeus also quotes Homer (eighth century BC) to embellish his writings and acclaims his name in the chapter on melancholy in the first book of his treatises (2). 
Although Aretaeus wrote prolifically on a great variety of subjects, his only work that has reached us is his famous treatise, entitled On the Causes, Symptoms, and Cure of Diseases, to be discussed later in this paper. Aretaeus himself mentions the titles of four other works that are no longer extant: On Fevers, On Diseases of Women, On Drugs, and On Surgery $(2,24)$.

\section{His Influence in the Early Middle Ages}

In terms of Aretaues' influence on other medical scholars, there is a lack of reference to his name in medical texts for several centuries. It is, indeed, a matter of curiosity that even though there is a considerable similarity to be found between Aretaeus' and Galen's writings and recommended therapies; Galen omits mention of Aretaeus' name in his writings. This should, however, not be interpreted as evidence that they were unknown to one another $(11,21)$. Two possible reasons may be behind this: Aretaeus and Galen may have been rival practitioners, as rivalry among medical scholars of that period was quite common. Second, in accordance with the established usage of living authors by one another, the one may have avoided mentioning the other by name in order not to form a biased opinion of his own works $(2,21)$.

The first report of Aretaeus' works occurs in the writings of Aëtius of Amida (sixth century AD), a medical writer and a chief physician in the court of Byzantine Emperor Justinian I. Aëtius adopts Galen's theories and provides information from Aretaeus on diseases (14). Alexander of Tralles (sixth century $A D$ ) and Paul of Aegina (seventh century AD) also quoted Aretaeus by name in their writings $(2,21)$. Aretaeus then remained unnoticed for nearly a thousand years. Arab physicians of medieval times who followed the Latin writings of authors such as Oribasius, Caelius Aurelianus, and Alexander of Tralles, were unaware of him (8). It was in the middle of the $16^{\text {th }}$ century that Aretaeus was again recognized when an original Greek manuscript of his celebrated treatise was discovered $(2,17)$.

\section{His Famous Work: On the Causes, Symptoms, and Cure of Diseases}

Aretaeus' treatises are the only extant works produced by a member of the Pneumatic School. These treatises, written in lonic Greek, include four texts divided into eight books as follows: i) On the Causes and Symptoms of Acute Diseases, ii) On the Causes and Symptoms of Chronic Diseases, iii) On the Cure of Acute Diseases, and iv) On the Cure of Chronic Diseases. The first five chapters of the first book as well as some parts of the third and fourth books have been lost (2) (Table I).

In parallel with the earliest printings in the $16^{\text {th }}$ century of other authors of antiquity, the first edition of Aretaeus' treatises was the Latin translation of Julius Paulus Crassus, a professor of medicine at Padua University. This translation was printed in 1552 in Venice, then reprinted in 1554 in Paris where the first Greek edition was also issued by Jacobus Goupylus in the same year $(22,27)$ (Figure 1).
These translations received such high praise from medical scholars in Europe that soon after, in 1574, an engraved portrait of Aretaeus was included in a book by Johannes Sambucus (1531-1584), a Hungarian physician and a humanist scholar, which compiled icons of ancient and modern physicians and philosophers (Figure 2). Many subsequent editions and commentaries in Latin and original Greek, as well as translations into several European languages, appeared later, even until the $21^{\text {st }}$ century (27). Among them, the original Greek version and its English translation by Francis Adams (1796-1861), published by the Sydenham Society in 1856, has been one of the most cited primary references on Aretaeus' writings $(5,19)$.

\section{Aretaeus' Contributions to Medicine}

What makes Aretaeus so unique and significant for medical history is his remarkable ability to make keen observations

\section{A RETAEI CAPPADOCIS MEDICI INSIGNIS AC VETVSTISSIMI L I B R I S E P T E M \\ Nunc primum e tenebris eruti \\ A IVNIOPAVLO CRASSO PATAVINO accuratißime in latinum formonem uerfi.

$$
\text { R VFFI EPHESII }
$$ \\ De corporis humani partium appellationibus LIBRI TRES, \\ AB EODEM IVNIO PAVLO CRASSO latinitate Donati.}

Quxin omnibus his libris fcitu ac memoria digna habentur, INDEX LOCVPLETISS. Operis calci appofitus demonftrabit.

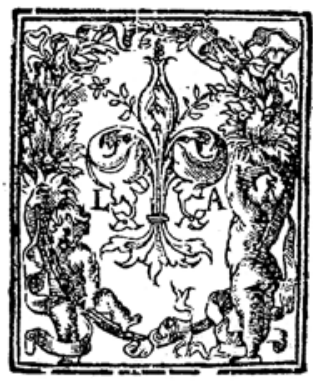

VENETIISAPVDIVNTAS.

$M$ D I I I

\section{Cum fummi Pontificis Senatusq́;.Veneti}

Decretis ad Annos dccem.

Figure 1: The first Latin edition of Aretaeus' treatise (1552) (Courtesy of the Wellcome Trust Library). 
Table I: Contents of Aretaeus' Books (Based on F. Adams' English Translation of 1856)

\begin{tabular}{|c|c|c|}
\hline Name of the Book & Book no. & Contents \\
\hline $\begin{array}{l}\text { On the Causes and Symptoms of } \\
\text { Acute Diseases }\end{array}$ & $\mathrm{I} / \mathrm{I}$ & $\begin{array}{l}\text { Phrenitis, }{ }^{*} \text { lethargy, }{ }^{*} \text { marasmus, }{ }^{*} \text { apoplexy, }{ }^{*} \text { paroxysm of epileptics, }{ }^{* *} \\
\text { tetanus, angina or quinsy, affections about the uvula, ulcerations about the } \\
\text { tonsils, pleurisy }\end{array}$ \\
\hline $\begin{array}{l}\text { On the Causes and Symptoms of } \\
\text { Acute Diseases }\end{array}$ & $\mathrm{I} / \mathrm{II}$ & $\begin{array}{l}\text { Pneumonia, bringing up of blood, syncope, causus or ardent fever, cholera, } \\
\text { ileus, acute affections about the liver, acute disease of the vena cava, acute } \\
\text { affections of the kidneys, acute affections about the bladder, hysterical } \\
\text { suffocation, satyriasis }\end{array}$ \\
\hline $\begin{array}{l}\text { On the Causes and Symptoms of } \\
\text { Chronic Diseases }\end{array}$ & II/I & $\begin{array}{l}\text { Preface, cephalaea, vertigo or scotoma, epilepsy, melancholy, madness, } \\
\text { another species of mania, paralysis, phthisis, persons affected with } \\
\text { empyema, abscesses in the lungs, asthma, pneumodes, liver, spleen, jaundice } \\
\text { or icterus, cachexia or bad habit of body }\end{array}$ \\
\hline $\begin{array}{l}\text { On the Causes and Symptoms of } \\
\text { Chronic Diseases }\end{array}$ & II/II & $\begin{array}{l}\text { Dropsy, diabetes, affections about the kidneys, those in the bladder, } \\
\text { gonorrhea, stomachic affections, coeliac affection, colics, dysentery, lientery, } \\
\text { affections of the womb or hysterics, arthritis and sciatica, elephas or } \\
\text { elephantiasis }\end{array}$ \\
\hline On the Cure of Acute Diseases & III/I & $\begin{array}{l}\text { Preface, cure of phrenitics, cure of lethargics, cure of marasmus, cure of } \\
\text { apoplexy, }{ }^{* *} \text { cure of paroxysm of epileptics, cure of tetanus, cure of quinsy, }{ }^{* *} \\
\text { cure of the affections about the columella or uvula, cure of the pestilential } \\
\text { affections about the pharynx, cure of pleurisy }\end{array}$ \\
\hline On the Cure of Acute Diseases & III/II & $\begin{array}{l}\text { Cure of peripneumonia, cure of the bringing up of blood, cure of cardiac } \\
\text { affections, cure of cholera, cure of ileus, cure of the acute affections about } \\
\text { the liver, cure of the acute disease of the dorsal vein and artery, cure of the } \\
\text { acute disease in the kidneys, cure of the acute affections about the bladder, } \\
\text { cure of the hysterical convulsion, cure of satyriasis }\end{array}$ \\
\hline On the Cure of Chronic Diseases & IV/I & $\begin{array}{l}\text { Preface, cure of cephalaea, cure of vertigo, cure of epilepsy, cure of } \\
\text { melancholy, }{ }^{* *} \text { cure of phthisis, }{ }^{* *} \text { cure of the liver, }{ }^{* *} \text { cure of the spleen }{ }^{* *}\end{array}$ \\
\hline On the Cure of Chronic Diseases & IV/II & $\begin{array}{l}\text { Cure of dropsy, }{ }^{*} \text { cure of diabetes, cure of calculus and ulceration of the } \\
\text { kidneys, }{ }^{* *} \text { cure of gonorrhea, cure of stomachics, cure of coeliacs, }{ }^{* *} \text { cure of } \\
\text { arthritis and ischiatic diseases, cure of elephas }\end{array}$ \\
\hline
\end{tabular}

${ }^{*}$ not extant, ${ }^{* *}$ partially extant.

as well as his vivid and accurate descriptions of a variety of diseases, using as few words as possible, unlike most scholars of his era who wrote lengthy descriptions.

Indeed, his work, On the Causes, Symptoms, and Cure of Acute and Chronic Diseases, was perspicuously written with picturesque accuracy. Aretaeus offered clinical descriptions of a number of diseases among which he gave the classic accounts of asthma, elephantiasis, epilepsy, pneumonia, tetanus, uterus cancer and different kinds of insanity $(4,10$, $12,20,22,25,26)$. He differentiated nervous diseases and mental disorders, described hysteria, headaches, mania and melancholia (1). He also rendered the earliest clear accounts on coeliac disease, diabetes, diphtheria and heart murmur as well as the first clear differentiation between cerebral and spinal paralysis $(7,9,21)$.

Here are some major examples of his contributions to diagnostic medicine:

\section{Coeliac Disease}

Long before Samuel Gee's (1839-1911) description of coeliac disease in 1887, Aretaeus renders one of the earliest clinical accounts on this disease. He claims that it is more common among the aged and particularly in women, perhaps because these patients are believed more deficient in natural heat (6, 19). He draws a clear distinction between the chronic coeliac state and a continuous diarrhea that occurs in children through transitory intemperance of food $(2,5)$.

\section{Diabetes}

Aretaeus' text on diabetes exemplifies his breadth of knowledge. He describes diabetes as a dreadful, chronic disease that develops over a long period of time, most commonly in women $(3,15)$. The following is a clinical description by him, with certain portions omitted (2): "Diabetes is a wonderful affection, not very frequent among men, being a melting down of the flesh and limbs into urine. 


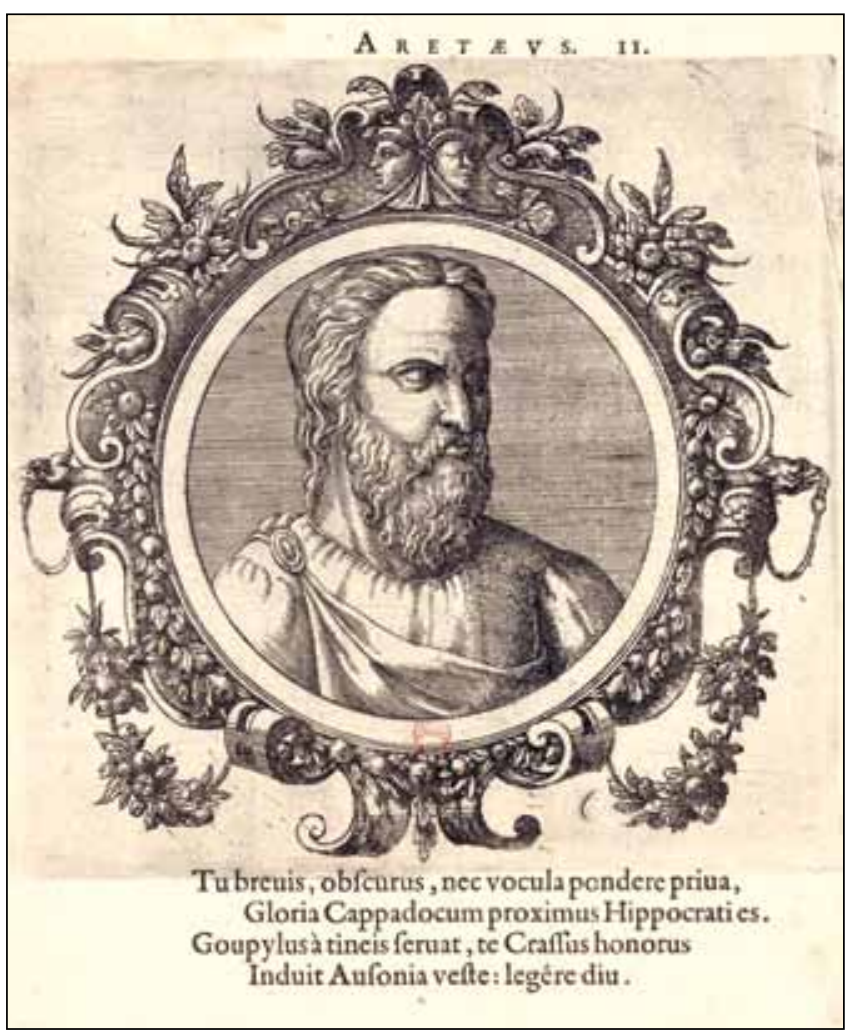

Figure 2: Engraved portrait of Aretaeus by loannes Sambucus (1574) (Courtesy of the Bibliothèque nationale de France).

Its cause is of a cold and humid nature, as in dropsy. The nature of the disease, then, is chronic, and it takes a long period to form; but the patient is short-lived, if the constitution of the disease be completely established; for the melting is rapid, the death speedy. Moreover, life is disgusting and painful; thirst, unquenchable; excessive drinking, which, however, is disproportionate to the large quantity of urine, for more urine is passed; and one cannot stop them either from drinking or making water."

On the causes of this disease, he believes that it may be derived from other diseases which attack the bladder and kidneys. Moreover, he gives diabetes its name and expresses the reason of choosing this word as follows $(2,21)$ : "[d]isease appears to me to have got the name of diabetes, as if from the

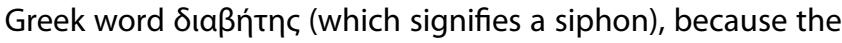
fluid does not remain in the body, but uses the man's body as

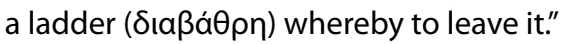

\section{Diphtheria}

Aretaeus gives the first recognizable description of diphtheria, its symptoms, complications and treatment $(22,26)$. At the beginning of the chapter on ulcerations about the tonsils, he classifies different types of tonsil ulcers, mentioning the usual benign and harmless ulcers, and the uncommon, infectious and at times deadly forms. If the disease spreads to the mouth and throat, the inflammation seizes the neck, and within a few days may cause fever, a stinking smell, hunger, and finally, death. The disease usually affects children before puberty due to their intemperance in desiring varied food and cold drink, and their shouting at play (2). Furthermore, in his account

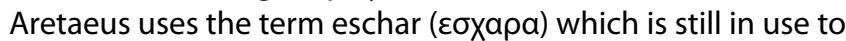
characterize diphtheria.

\section{Headaches}

Aretaeus makes a distinction between three different types of headache: i) cephalalgia, by which he indicates a shortlasting, mild headache; ii) cephalea, referring to a chronic type of headache; and iii) heterocrania, a paroxysmal headache on one side of the head. According to Koehler and Wiel (2001), in the later, Aretaeus described not only what is called a migraine in modern understanding; most probably he classified symptomatic headache and facial neuralgia as heterocrania as well (13).

\section{Heart Murmur}

In his discussion of syncope, Aretaeus describes a feeble pulse, palpitations and also heart murmur as follows (2): "[t] hose dying in such cases have symptoms of heart affections, namely, pulse, small and feeble, bruit of the heart, with violent palpitation, vertigo, fainting, torpor, loss of tone in their limbs, sweating copious and unrestrainable, coldness of the whole body, insensibility, loss of utterance."

\section{Tetanus}

Aretaeus gives the first elaborate description of a condition characterized by exceedingly painful spasms starting in the jaws and spreading to the rest of the body (16). According to him, the causes of these complaints include wounds, abortion, spasm owing to a severe blow in the neck and severe cold. Food is regurgitated through the nose, and suffocation sets in, with the face red and the eyes fixed. Although recovery is possible, the patient normally dies in agony within a short time (2).

Aretaeus' writings clearly indicate that he gave importance to a careful regulation of diet, muscular exercises, massage, and mild drugs $(15,24)$. He also attached great importance to practical experience, suggesting that a physician should be familiar with certain drugs or treatments by experience (4). The Pneumatic School also influenced his drug therapy which was characterized by a small number of simple remedies. The first of his routine therapeutic measures was bleeding, including scarification and the use of leeches, and then purging. These may extend for a period of up to ten days. When the patient's health allowed, he was encouraged to exercise; this was combined with a dietary regime consisting essentially of foods having diuretic properties and those which were easily digested and nourishing such as milk or wine. He also followed the conventional way of administering drugs in several different forms such as aqueous or vinous decoctions, cataplasms, and clysters (24).

Throughout the centuries following his work's discovery, among European physicians, Aretaeus was considered second only to Hippocrates in his wisdom and scientific acumen (16). 
Father of modern pathologic anatomy, the $18^{\text {th }}$ century Italian physician Giambattista Morgagni (1682-1771) recognized that Aretaeus had performed dissections and drew inspiration from his writings (27). A renowned French physician and the inventor of the stethoscope, René Laennec (1781-1826) was one of the admirers of Aretaeus as well, placing him with Hippocrates as the outstanding authority of antiquity on the classification and description of diseases $(21,22)$. Interestingly enough, an unpublished Aretaeus translation by Laennec, which had been preserved at the library of the University of Nantes for more than 150 years, was edited with a commentary by Mirko D. Grmek and published in 2000 (23). Sir William Osler (1849-1919), a famous Canadian physician who has been described as the Father of Modern Medicine, writes critically that the art of observation had come to a standstill in modern times as compared with the work of Aretaeus (18).

\section{CONCLUSION}

Aretaeus of Cappadocia's work is not only an outstanding example that reveals the scientific acumen of antique medicine, but is also a milestone in the history of diagnostic medicine. His eight-book treatise greatly influenced European physicians from the $16^{\text {th }}$ century on. This is proof positive that the history of medicine is not only important for the content it provides, but also because it brings a fresh way of critical thinking about a variety of subjects linked to modern medical practice.

\section{REFERENCES}

1. Angst J, Marneros A: Bipolarity from ancient to modern times: Conception, birth and rebirth. J Affect Disorders 67(1): 3-19, 2001

2. Aretaeus: The extant works of Aretaeus, the Cappadocian. F Adams (trans). London: Sydenham Society, 1856

3. Christopoulou-Aletra $\mathrm{H}$, Papavramidou $\mathrm{N}$ : Diabetes as described by Byzantine writers from the fourth to the ninth century AD:The Graeco-Roman influence. Diabetologia 51(5): 892-896, 2008

4. Couch $\mathrm{JH}$, Couch $\mathrm{HN}$ : The literary illustrations of Aretaeus of Cappadocia. Can Med Assoc J 33(5): 556, 1935

5. Dowd B, Walker-Smith J: Samuel Gee, Aretaeus, and the coeliac affection. BMJ 2(5909): 45, 1974

6. Gasbarrini G, Miele L, Corazza GR, Gasparrini A: When was celiac disease born? The Italian case from the archeologic site of Cosa. J Clin Gastroenterol 44(7): 502-503, 2010

7. Gemmill CL: The Greek concept of diabetes. B New York Acad of Med 48(8): 1033, 1972

8. Gutas D: Greek Thought, Arabic Culture: The Graeco-Arabic translation movement in Baghdad and early Abbasid society. London: Routledge, 1998

9. Haas LF: Aretaeus of Cappodocia (130-200). J Neurol Neurosur Ps 54(3): 203, 1991
10. Hajdu SI: A note from history: Landmarks in history of cancer. Cancer 117(5): 1097-1102, 2011

11. Henschen F: On the term diabetes in the works of Aretaeus and Galen. Med Hist 13(2): 190-192, 1969

12. Karamanou M, Androutsos G: Aretaeus of Cappadocia and the first clinical description of asthma. Am J Resp Crit Care 184(12): 1420-1421, 2011

13. Koehler PJ, Wiel WM: Aretaeus on migraine and headache. J Hist Neurosci 10(3): 253-261, 2001

14. Kudlien F: Untersuchungen zu Aretaios von Kappadokien. Mainz: Akademie der Wissenschaften und der Literatur, 1963

15. Laios K, Karamanou M, Saridaki Z, Androutsos G: Aretaeus of Cappadocia and the first description of diabetes. Hormones 11(1): 109-113, 2012

16. Leopold EJ: Aretaeus the Cappadocian. Ann Hist Med 2: 424435,1930

17. Oberhelman SM: Aretaeus of Cappadocia: On the chronology and the pneumatic physician of the first century AD. ANRW 37(2): 941-966, 1994

18. Osler W: The evaluation of modern medicine. New York: Yale University Press, 1921

19. Paveley WF: From Aretaeus to Crosby: A history of coeliac disease. BMJ 297(6664): 1646-1649, 1988

20. Pearce JM: Notes on tetanus (lockjaw). J Neurol Neurosur Ps 60(3): 332, 1996

21. Reed JA: Aretaeus, the Cappadocian: History enlightens the present. Diabetes 3(5): 419-421, 1954

22. Retief F, Cilliers L: Aretaeus of Cappadocia: The forgotten physician. Acta Academica 41(4): 23-39, 2009

23. Scarborough J: Arétée de Cappadoce: Des causes et des signes des maladies aiguës et chroniques. ISIS Baltimore 94(4): 707, 2003

24. Stannard J: Materia medica and philosophic theory in Aretaeus. Sudhoffs Archiv für Geschichte der Medizin und der Naturwissenschaften 48: 27-53, 1964

25. Tsoucalas G, Karamanou M, Laios K, Androutsos G: Aretaeus of Cappadocia and the first accurate description of uterine carcinoma. J BUON 18(3): 805-807, 2012

26. Tsoucalas G, Marineli F, Karamanou M, Laios K, Androutsos G: Aretaeus of Cappodocia - views on diphtheria. Le infezioni in Medicina 20(4): 313-315, 2012

27. Weber G: Areteo di Cappadocia: Interpretazioni e aspetti della formazione anatomo-patologica del Morgagni. Firenze: Accademia Toscana di Scienze e Lettere, 1996

28. Wellmann M: Die pneumatische Schule bis auf Archigenes - in ihrer Entwickelung dargestellt. In: Philologische Untersuchungen. Berlin: Weidmannsche Buchhandlung, 1895: 23-64 